\title{
Editorial by Valerie Braun and a good-bye note from Brigitte Scott
}

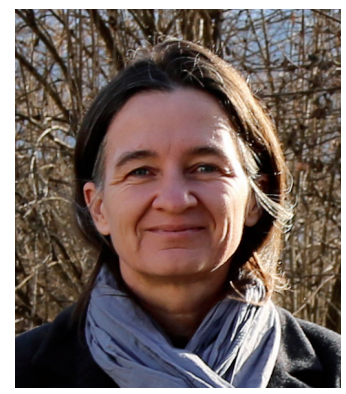

This issue of eco.mont is in many ways quite special!

First of all, there are changes in the eco.mont team. With Axel Borsdorf and Bernd Stöcklein retiring in 2016, two new members have joined the editorial team. And as eco.mont has gone from strength to strength this last year, we decided to expand the editorial board with two new members. Finally, yet importantly, this is Brigitte Scott's farewell issue.

Martin Coy succeeds Axel Borsdorf as one of the editors. He is Professor of Applied Geography and Sustainability Studies at the Institute of Geography at Innsbruck University.

Astrid Wallner, Christoph Moning and Matej Gabrovec have joined the editorial board of eco.mont. Astrid Wallner is coordinator of Swiss Park Research at the Swiss Academies of Arts and Sciences. Christoph Moning is Professor for Zoology and Animal Ecology at the University of Applied Sciences of Weihenstephan-Triesdorf (Germany) and succeeds Bernd Stöcklein, who was a member of the editorial board of eco.mont from the beginning and is still supporting us as a senior consultant. Matej Gabrovec is Assistant Professor at the Anton Melik Geographical Institute at Ljubljana (Slovenia). All have a special interest in protected mountain areas and have worked on a variety of research topics in Großes Walsertal Biosphere Reserve (Austria), UNESCO World Heritage Jungfrau-Aletsch-Bietschhorn (Switzerland), Triglav National Park (Slovenia) and protected areas in Bavaria (Germany).

This is also Brigitte Scott's last issue as the English editor for eco.mont. I would like to thank her in the name of the whole team for the endless effort she has put into eco.mont. Mary Rigby, a language editing professional from Glasgow, Scotland, will succeed her and has already worked with us on this issue. Thank you Mary!

In the name of the editorial team and editorial board, I would like to welcome all five new members to our team and we are all looking forward to working together.

Second, this is the first time that we have published a special issue co-edited by Hubert Job in parallel with our regular issue. The articles of both issues are available by open access. Because of the double publication, this issue is slightly thinner than normal. It was important for us to stay committed to our regular bi-annual platform to allow our authors to publish their work on protected mountain areas, but this time we did not issue a special call for scientific articles.

Geographically the articles in this issue cover protected areas within the Alps, the Carpathians and the Andes, dealing with sustainable development, human influences on fish fauna, environmental restoration work, drones as a monitoring tool for detecting human winter activities and their influences on the capercaillie, an introduction to the Tyrolean Alps LTSER platform and ends with a glimpse in the EUROPARC Conference 2016. The issue is rounded up by a book review on the Plant Life of the Dolomites, introduces us to a transdisciplinary University Course in Innsbruck on human living space in transition and invites us to the EuroMAB Meeting 2017 in France. The topics are as diverse as the challenges protected areas face globally. Our goal at the very beginning of eco.mont was to form a link between the results of scientific research and the management of protected areas and we are still devoted to this goal as the articles in this issue show.

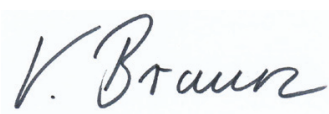

Valerie Braun

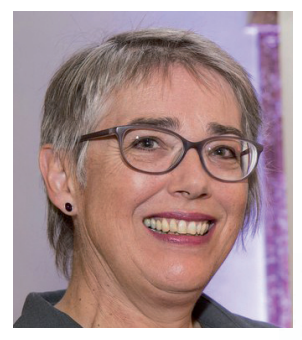

Over the last seven years my work on the articles submitted to eco.mont has not only been very enjoyable, but has allowed me to glimpse the hugely varied work done by researchers and managers in protected mountain areas. This issue is already a joint effort with Mary Rigby. I wish all the people working on eco.mont every success, but my special thanks go to Valerie Braun - never a dull moment!

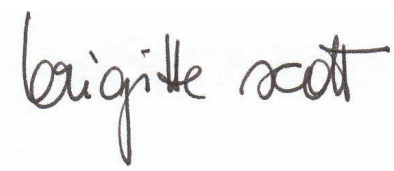

Brigitte Scott 
Related projects according to the European Mountain Pool

At the editorial office of eco.mont, we maintain the European Mountain Pool on research in European protected mountain areas. http://4dweb.proclim.ch/4dcgi/ProtAreas/en/BuildSearch_ ProtArea

eco.mont - Volume 9, Number 1, January 2017

Do large private protected areas contribute to sustainable development? A case study from the Huilo Huilo Biological Reserve in Neltume, Chile by Benedikt Hora

The fishes' last stand: the fish fauna of Jiu River Gorge, between decades of coal mining and present day hydroenergetic works by llie C. Telcean, Roland E. Mihut \& Diana Cupşa

Vegetation analysis and estimation of forest reconstitution time in protected areas of Val Camonica (Southern Alps) where a commercial mixture of seeds was sown by Luca Giupponi, Gian Battista Bischetti \& Annamaria Giorgi

Using drones as a monitoring tool to detect evidence of winter sports activities in a protected mountain area by Stefan Weber \& Florian Knaus

The Tyrolean Alps LTSER platform - providing scientific insights for better management of protected areas by Sarah Kerle \& Ulrike Tappeiner
Related projects in the European Mountain Pool

Nicole Thompson: Planning and Sustainable Land Management in England's National Park. CH-5400

Frieder Voll: A systemic perspective on sustainable governance of protected areas. CH-5393

Urs Wiesmann: World Natural Heritage and Sustainable Regional Development. CH-4378

Katharina Conradin: Does World Natural Heritage status trigger sustainable regional development efforts? CH-5379

Hu Maolin: Freshwater fish species richness and conservation of mountain streams in the Jinggangshan National Nature Reserve, China. CH-5384

Sabine Güsewell: Developmet of seedings on embankments in the Swiss National Park. CH-1178

Marcel Hunziker: The effect of communicative and on-site measures on the behaviour of winter sports participants. CH-5387

Brigitta Erschbamer: Ongoing changes at the longterm monitoring sites of Gurgler Kamm Biosphere Reserve, Tyrol, Austria. CH-5392 